\title{
SMART SPECIALIZATION, ELEMENT OF REGIONAL DEVELOPMENT*
}

\author{
Florina Popa \\ Institutul de Economie Naţională, Academia Română \\ (Institute of National Economy, Romanian Academy) \\ florinapopa2007@gmail.com
}

\begin{abstract}
Research-Development and innovation expenditure (conditions of a few high specializations in different fields of science) know an increasing importance, both at countries level and regions, on the background of challenges that occur in economic growth, at European Union level, involving investment increase in knowledge, respectively, education, professional training, research and development. The existence of a good model of territorial development means finding a strategy and governance able to create new economic activities that capitalize the competitive and comparative advantages of territorial potential, in global context. The new strategy of economic transformation at local level, the smart specialization, aims to promote efficient and effective use of public investment in research, based on innovation encouragement, at regional level, that should lead to economic growth and prosperity of regions. The implementation of strategy's instruments involves an integrated approach, by using own forces and potential of each region, that should meet the requirements of European Agenda, for growth and competitiveness achievement. By identifying the fields with high potential, at regional level, and their strengthening, the smart specialization can concur to regions access on global markets and international value chain. The study briefly expounds the concept of smart specialization and its constituent sizes, principles of action in the field of research-development and innovation. There are also considered the implementation stages of "strategy", in the interventions at regional level, as well as the advantages and risks that it entails.
\end{abstract}

\section{Keywords}

strategy; development; implementation; regional potential; competitive advantage

\section{JEL Classification}

O38; R11; R58

\section{Introduction}

A successful economic development means a continuous upward process, in which the business environment of a nation evolves in order to support and encourage complex and productive competitive methods.

Knowledge, the adoption of new organizational solutions and new technologies, continuous innovation are elements which help ensure the economic development, the competitive advantage, the activity of the research-development sector and the capacity of economies to implement its results being determinant for innovation.

*This article is part of the scientific research paper, for 2015, of the Institute of National Economy - Romanian Academy- "Creşterea competitivităţii economice şi specializare inteligentă, la nivel regional în România", achieved by $\mathrm{PhD}$. Daniela Antonescu-coordinator, Florina Popa. 
In the context of the challenges involved in the economic growth at the level of the European Union, we distinguish the importance of the expenses incurred for researchdevelopment and innovation (conditions of certain high specializations in different fields of science), both at the level of the countries and at the level of the regions, which involves an increasing investment in knowledge, namely in education, professional improvement, research-development.

A sustainable growth, at the level of the Member States, is conditioned by improving the Single Market, by increasing competitiveness, by promoting innovation in industry and services.

The existence of a good territorial development model consists of finding a strategy and an administration capable to create new economic activities, which should improve the competitive and comparative advantages of the territorial potential, in global context.

\section{Conceptual elements}

The new strategy of economic transformation at local level, namely smart specialization, aims to promote the efficient and effective use of public investments in research, based on stimulating innovation at regional level, which should lead to economic growth and prosperity of the regions.

The concept regarding the "smart specialization" appeared in the 2000s, during the European debates, initiated by a group of "European Knowledge for Growth" experts, regarding the motivation of the gap between the European Union competitiveness, which is lower, in relation to that of the United States. The formulated hypothesis was the existence of a weaker economic and technological specialization of the European Union, as well as the existence of a lower capacity to prioritize the efforts and resources, in relation to that across the Atlantic.

The new territorial development model - smart specialization - whose purpose is increasing the effectiveness and the efficiency of economic systems, in order to contribute to a sustainable development, was integrated into the new Regional Policy of the European Commission for 2014-2020, as Regional Smart Specialization Strategies (RIS3), process which highlights a new administration model developed for certain more effective and more efficient economic systems.

The promotion of the concept by the European Commission had as purpose a better motivation of the investments in research-development-innovation provided by the EU Cohesion Policy.

For this purpose, the European Commission recommended to national and regional authorities of the Member States to elaborate research and innovation strategies for smart specialization, which should lead to a more efficient use of the funds, to an intensification of the associations between the community, national and regional policies, between the investments of the public sector with the private one; thus the smart specialization becomes an ex-ante conditionality for the access of the regions to these funds.

The implementation of Smart Specialization Strategy tools involves an integrated approach, by using the forces and the potential of each region, which should meet the requirements of the European Agenda for achieving growth and competitiveness, the main measures being oriented towards:

- reviving the traditional sectors, by developing new activities with higher added value;

- $\quad$ finding new market opportunities;

- adopting and disseminating new technologies; 
- directing the investments with focus on the research-innovation field, by using the regional potential;

- exploring new forms of innovation which should lead to technological essential changes.

Carrying out smart specialization strategies involves management (national/regional) authorities, stakeholders, universities and other higher education institutions, industry, social partners, in an entrepreneurial discovery process.

At regional level, smart specialization is considered "the process by which the region can find its competitive advantage and build a particular development strategy, adapted to the advantages and constraints specific to the territory, focusing the resources on technological fields of activity and sectors in which they hold a comparative advantages, proven on one or more chains of international value by targeting excellence"'.

\subsection{Constitutive dimensions of smart specialization}

Defined by "the establishment of priorities that at a regional-level take place in a series of activities and/or technology domains, and that are potentially competitive and able to generate new business in a global context faced competition from other places" (Del Castillo, Barroeta, Paton, 2012), the concept consists of three basic dimensions:

1. Global context. Specialization means the registration in the global value chain in which the region has to be able to position itself, which implies the definition of the competitive advantages, namely the identification of the elements of differentiation which give it an advantage in the competition with other locations.

2. Technological specialization, in regard to the identification of the fields in which the region holds the competitive advantage, which involves the prioritization and the orientation of the efforts and resources towards the innovative technological sectors in which the region holds a competitive advantage and actors able to achieve excellence and added value.

3. A coherent diversification (related variety) implies the orientation of the specialization towards the technological fields or sectors which are in close relation to the purpose of maximizing the positive externalities of knowledge between related technological fields, which should lead to developing certain new technological, innovative fields.

The new forms and tools, in the research-development field, proposed by smart specialization, are based on a set of principles, namely:

a)The central role of entrepreneurial discovery, a process in which all the actors in the entrepreneurial field interact with each other, having a significant role in choosing the specializations with a strong growth potential. "Entrepreneurial discovery" also seeks the aggregation of knowledge elements (technological, economic, social elements) in order to identify the opportunities for developing new innovative fields, which generate growth and jobs.

b)Taking into consideration, different from the focus on research-innovation, the aptitudes and other advantages of the area: geographic position, population structure, natural resources, aspects of the demand, of the supply - elements which contribute to stimulating innovative activities in the region.

c)The possibility to cooperate with potential innovators outside the borders of the region ensures a global perspective on competitive advantages.

${ }^{1}$ L`Europe s`engage en France avec Europ`Act, Guide pour la préparation des stratégies de spécialisation intelligente des régions françaises, 2012, http://www.europe-en-france.gouv.fr; 
d)The perspective of involving all the regions in the implementation of smart specialization, both of the advanced ones, in the research-development field, and of the less competitive ones, for this purpose, each region taking into consideration:

-initiating a self-assessment of the advantages, of the knowledge potential they have, of the skills of the actors who promote diffusion of knowledge and innovation;

-emphasizing the efforts for each sector of innovative technological activity in which they hold the competitive advantage.

The regions with lower performance have the possibility to build a strategy corresponding to the potential and evolutions of the market, by taking into consideration their perspectives of economic growth capacities, avoiding the field in which other actors distinguished themselves as leaders.

e)The role of public policies. In implementing the conditions for cooperation and interaction between the public and private actors, including the research organizations, universities, the responsibility belongs to the public power which should express itself by:

-creating incentives for entrepreneurs;

-estimating the selected specializations;

-supporting certain complementary investments (education, training);

-supporting the application of the new strategies;

-ensuring the fact that the expected measures correspond to the needs of the local population.

f)The development of the cooperation between regions which invent technologies and the other regions which apply them, the promotion of the contacts between companies and clusters, improves the access and diffusion of new technologies.

The notion of smart specialization can be considered the result of a theoretical consolidation of the works of the economists regarding the competitive advantage of the scale value and productivity chain in a globalized economy. This "involves a process of developing a view, identifying the competitive advantage, establishing the strategic priorities and using smart policies, in order to maximize knowledge based on the potential of developing a, strong or weak, high-tech or low-tech region"2.

The interventions at regional level, by implementing the smart specialization strategies, have to be relevant, based on realistic evaluations, by entrepreneurial actors, process which has to be structured in more stages, as follows (Table 1):

\section{Table 1 Stages of the smart specialization implementation}

\begin{tabular}{|l|l|}
\hline Structure & Stage \\
\hline $\begin{array}{l}\text { 1. Identifying and selecting certain } \\
\text { technological fields/sectors towards which } \\
\text { the region aims to orient, in priority, its } \\
\text { efforts and available resources; analyzing } \\
\text { the regional potential for innovation. }\end{array}$ & $\begin{array}{l}\text { 1. Initiating the processes and } \\
\text { elaborating an overview regarding the } \\
\text { perspectives of the region; identifying } \\
\text { the smart specialization model is the } \\
\text { result of a "bottom-up" approach, the } \\
\text { support coming from the regional } \\
\text { government, "top-down". }\end{array}$ \\
\hline 2. Defining and implementing priorities, & 2. Designing and implementing the \\
\hline
\end{tabular}

$\begin{array}{llllll}{ }^{2} \text { What is Smart Specialisation? Smart Specialisation Platform } & \text { S3 }\end{array}$
http://s3platform.jrc.ec.europa.eu/s3pguide 


\begin{tabular}{|c|c|}
\hline $\begin{array}{l}\text { establishing a complex of coherent policies, } \\
\text { based on certain realistic, controllable } \\
\text { objectives. }\end{array}$ & $\begin{array}{l}\text { smart specialization strategy by } \\
\text { objectives and programs which } \\
\text { involve all regional stakeholders; it is } \\
\text { the basic element of entrepreneurial } \\
\text { discovery. }\end{array}$ \\
\hline $\begin{array}{l}\text { 3. The existence of the monitoring system } \\
\text { and the assessment which have to ensure the } \\
\text { process transparency - basic element in } \\
\text { increasing the funds of the European } \\
\text { regional policies. }\end{array}$ & $\begin{array}{l}\text { 3. Assessment and monitoring based } \\
\text { on which the continuous improvement } \\
\text { and the maintenance of efficiency and } \\
\text { effectiveness should be ensured. }\end{array}$ \\
\hline \multicolumn{2}{|c|}{$\begin{array}{l}\text { Source: Jaime del Castillo, Barroeta, B., Paton, J. (2011), “Converting Smart Specialisation into a Regional } \\
\text { Strategy”, Working Paper Series, iD INFYDE Working Paper Series Year 1, Volume } 2 \text { No.1; European } \\
\text { Commission (2013), “The Role of Clusters in Smart Specialisation Strategies”, Luxembourg: Publications } \\
\text { Office of the European Union, } \\
\text { https://ec.europa.eu/research/evaluations/pdf/archive/other_reports_studies_and_documents/clusters_smart } \\
\text { _spec2013.pdf. }\end{array}$} \\
\hline
\end{tabular}

Following the path of a smart specialization involves the discovery of the fields in which the country/region can be more competitive, in relation to others, which means "an entrepreneurial discovery process", consisting of searching for new ideas, new partners, developing creative solutions, combining the potential advantages of the area, in order to reach the final purpose, bringing new solutions on the market, promoting growth and jobs.

Smart specialization can create a competitive advantage for the region, but, at the same time, its opportunities may, also, involve certain risks, like for instance (Table 2):

Table 2 Advantages and risks of smart specialization

\begin{tabular}{|l|l|}
\hline \multicolumn{1}{|c|}{ Advantages } & \multicolumn{1}{|c|}{ Risks } \\
\hline $\begin{array}{l}\text { Establishing priority areas } \\
\text { Facilitating the orientation of the regional } \\
\text { capacities of research, development and } \\
\text { innovation, according to the market } \\
\text { opportunities. }\end{array}$ & $\begin{array}{l}\text { Differences between the regions } \\
\text { regarding the entrepreneurial capacity } \\
\text { may increase the gaps between the } \\
\text { regions. }\end{array}$ \\
\hline $\begin{array}{l}\text { Specialized diversification } \\
\text { It may lead to a variety of the } \\
\text { specialization areas of the economy. }\end{array}$ & $\begin{array}{l}\text { In the absence of an entrepreneurial } \\
\text { critical mass, of the share capital, of the } \\
\text { experience in regional administration, the } \\
\text { process of regional administration cannot } \\
\text { be applied. }\end{array}$ \\
\hline $\begin{array}{l}\text { Global context } \\
\text { Defining the priority areas of } \\
\text { specialization in accordance with the } \\
\text { global context increases the chances of } \\
\text { success. }\end{array}$ & $\begin{array}{l}\text { The administration in an open economy } \\
\text { is not widespread yet, and success } \\
\text { depends on the cooperation potential in } \\
\text { the region-country-Europe space. }\end{array}$ \\
\hline
\end{tabular}


Source: Jaime del Castillo, Paton, J. quote Paton and Baroetta, (2012), in“What S3 means for European Regions, different forms of smart specialization?”, http://www.know-hub.eu/knowledge-

base/encyclopaedia/what-s3-means-for-regions-different-forms-of-smart-specialisation.html

Smart specialization is a knowledge process whose life span differs, in time, according to regional capacities and evolution tendencies in the environment.

Entrepreneurial discovery does not follow a unique pattern, any region can act in the direction of creatively combining technologies, of finding business opportunities, of increasing the number of jobs and the wellbeing level.

\section{Conclusions}

Promoting the concept of smart specialization means an innovation in the European regional policy, oriented towards a strong thematic focus, the purpose being that of defining, at the level of each territory, a strategy for research and innovation, adapted to the advantages and conditions in the area and to the European objectives regarding research-development-innovation.

By identifying the fields with high potential, at regional level, and by strengthening them, smart specialization may contribute to the access of the regions on the global markets and in the international value chain.

The smart specialization approach is a guarantee of the effective use of the funds and of an efficient coordination between regional, national and European policies, contributing to the increase of the EU competitiveness, by re-enhancing its potential, which will allow it to confront and to resist international competitiveness and defiance at global level.

\section{References}

Edmonds, T., Jarvis T., McGinness, S. (2000), Regional Competitiveness \& the Role of the Knowledge Economy. House of Commons Library, Research Paper 00/73 27 July, available at http://researchbriefings.files.parliament.uk/documents/RP00-73/RP00-73.pdf

Del CastilloJ., Paton, J., Saez A. (2013), Smart Specialisation and Clusters: The Basque Country Case, Smart Regions for a Smarter Growth Strategies: New challenges of the regional policy and potentials of cities to overcome a worldwide economic crisis, available at www.reuniunesdesestudiesregionales.org/oviedo/2013;

Del Castillo, J.; Barroeta, B.; Paton, J. (2012), Smart Specialisation Strategies RIS3: A quick guide. INFYDE Working Paper, Year 2, Vol.1;

Del Castillo, J., Barroeta, B., Paton, J. (2011), Converting Smart Specialisation into a regional strategy, iD INFYDE Working Paper Series Year 1, Volume 2 No.1, available at http://www.infyde.eu/archivos/archivo_68.pdf, http://s3platform.jrc.ec.europa.eu/s3pguide.

Del Castillo J., Paton, J., What S3 means for European Regions, different forms of smart specialisation? European Union, available at http://www.knowhub.eu/knowledge-base/encyclopaedia/what-s3-means-for-regions-differentforms-of-smart-specialisation.html;

Ketels, Christian, H., M., (2013),Clusters and Cluster Initiatives: Recent Learnings, Current Challenges, Harvard Business School, available at http://www.slideshare.net/TCINetwork/clusters-and-cluster-initiativesrecentlearnings-current-challenges; 
Mempel-Śnieżyk, A. (2013),Smart Specialisation and Clusters in Economic Growth, Prace Naukowe Uniwersytetu Ekonomicznego We Wrocławiu, Research Papers of Wroctaw University of Economics Nr. 324, 2013,Economy and Space, pages 92-103,Wrocław, Poland, www.Depot.Ceon.Pl;

Paton, J., Barroeta, B. (2012),RIS3 policy typology: the optimun policy mix for a regional smart specialization;

European Commission- Directorate-General for Research and Innovation (2013), The Role of Clusters in Smart Specialisation Strategies, Luxembourg Publications Office of the European Union, available at https://ec.europa.eu/research/evaluations/pdf/archive/other_reports_studies_an d_documents/clusters_smart_spec2013.pdf;

European Commission, Joint Research Centre. Innovation and Growth available at .https://ec.europa.eu/jrc/en/science-area/innovation-and-growth;

European Commission, Research and Innovation - Regional Dimension of Innovation - Smart Specialisation, available at http://ec.europa.eu/research/regions/index_en.cfm?pg=smart_specialisation;

European Commission (2014), Smart Specialisation and Europe's Growth Agenda,Luxembourg: Publications Office of the European Union, available at http://ec.europa.eu/regional_policy/sources/docgener/studies/pdf/smart_spec_g rowth_agenda.pdf;http://ec.europa.eu/regional_policy/en/information/publicati ons/brochures/2014/smart-specialisation-and-europes-growth-agenda;

Comisia Europeană (2012), Specializarea Inteligentă. Motorul viitoarei creşteri economice în regiunile din Europa,Panorama, Inforegio Nr. 44,Uniunea Europeană, available at http://ec.europa.eu/regional_policy/sources/docgener/panorama/pdf/mag44/ma g44_ro.pdf;

http://ec.europa.eu/regional_policy/ro/information/publications/panoramamagazine/2012/panorama-44-smart-specialisation-the-driver-of-futureeconomic-growth-in-europe-s-regions;

Regiunea Centru, Agenţia pentru dezvoltare regională Centru. Informare privind realizarea Strategiei de Specializare Inteligentă a Regiunii Centru (RIS3),Strategia de Specializare Inteligenta a Regiunii Centru pentru perioada 2014-2020, available at http://www.adrcentru.ro/; www.regio-adrcentru.ro;

OECD (2012), Cluster Policy and Smart Secialisation. OECD Science, Technology and Industry Outlook, OECD, available at https://www.oecd.org/sti/outlook/eoutlook/stipolicyprofiles/interactionsforinnovation/clusterpolicyandsmartspeci alisation.htm

L`Europe s`engage en France avec Europ`Act.Guide pour la préparation des stratégies de spécialisation intelligente des régions francaises, Guide Édition Novembre2012, available at http://www.europe-en-france.gouv.fr/Centre-deressources/Etudes-rapports-et-documentation/Guide-pour-la-preparation-desstrategies-de-specialisation-intelligente-des-regions-francaises;

What is Smart Specialisation? Smart Specialisation PlatformS3, available at http://s3platform.jrc.ec.europa.eu/s3pguide. 